\title{
Increasing Curiosity Character of Student Using Movable Book
}

\author{
Yayan Ari Subangkit ${ }^{1}$, Subuh Anggoro ${ }^{2}$ \\ \{ yayanarisubangkit@gmail.com ${ }^{1}$, subuhanggoro@ump.ac.id ${ }^{2}$ \} \\ ${ }^{1}$ SD Negeri 1 Mangunegara \\ ${ }^{2}$ Universitas Muhammadiyah Purwokerto
}

\begin{abstract}
Character is a part of human behavior. Everyone can value another one by seeing their character. Positive character is an important aspect to be built so early by educators on their students. One most important character to be built on student is curiosity. Curiosity helps students to understand knowledge and develop environment's care. Teacher can use instructional media to help student develop their curiosity character. Movable book is a learning media which have special book creatures. Movable book doesn't only have 2D shaped but also has a section that can be folded, pulled, and can be moved. This study aims to increasing of students' curiosity using movable book. This research used R\&D method to development of movable book. Subjects of this research were fourth grade elementary school students in Sokaraja Subdistrict, Banyumas Regency, Indonesia. Techniques of collecting data of this research were observation and questionnaire response. The research outcomes showed that movable book ultimately able to increase students' curiosity. The findings proved by observation of activity that showed the students' more active in learning process. Therefore, students' questionnaire response recognized the increasing of curiosity character. Based on findings result, researcher concludes that movable book can be choosen by teachers as one of instructional media to improving students' curiosity.
\end{abstract}

Keywords: curiosity, movable book, instructional media, elementary school

\section{Introduction}

Character is a pattern underlies human behavior which is used during human life continously. Character is a personality of the human being. Character is personality which is believed and used as a foundation for perspective, thinking, attitude, and performing [1]. Teacher as one of main character of education has responsibility to building students' curiosity through learning process. When student has high curiosity, they will try to make the living of environment around better. Nevertheless, the students has low curiosity and the teacher also has difficulties to developing students' curiosity. In fact, the people doesn't care about potential at environment. Trashes and animals' stink take places in everywhere. That condition happens due to lack of pupil's curiosit to the environment and knowledge.

The reason elementary school choosen by researcher is character is the stagnant attitude of human which is the outcome of the continuous and progressive cultivation of the past [2]. Despite in school, character can be developd in every where and every time. For examples, parents is a lead factor to develop students' character because children spend longer time at home rather than at school. It is so possible to growing students' curiosity, but this study obtaining students' curiosity with joyful and meaningful ways [3]. 
This research aims to measure the students' curiosity by using movable book on elementary school. Movable book is not an usual book. Researcher make an improvement on usual book to be interesting book so the students have entushiasm in reading book. Students does not like reading book that obtained full of transcription and without something colorfull. Thus, makes the students feel bored and tired so quickly. Movable book is a "magical book" which has appeared into the world for long time ago. Unfortunately, the existance of movable book was disguised by other books such as pop up and flip flap books. By using movable book, students not only read book but also can play it because movable book works by movable mechanism. Movable book have simple details and can be customized so easily by editing the content and purpose of making it.

\section{Methods}

This research used quasy experiment. The subjects of this research were fourth grade students from 4 elementary schools in Sokaraja Subdistrict, Banyumas Regency, Indonesia. Needs analysis was performed on all four schools. Therefore, fourth schools are divided into one class to performed eligibility test and another classes did the effectiveness test of movable book.

Techniques of collecting data employed questionnaire, assessment scale, interview, and observation. Needs analysis included interviews and questionnaires of student needs analyzed by qualitative analysis techniques of Miles and Huberman. However, the observation and questionnaire students' curiosity was analyzed statistically using Microsoft Excel application and SPSS 23.

The movable book effectiveness was measured by applying it in learning process. The teacher who teach in the classroom did learning process as usual. Nevertheless, teacher used movable book as instructional media at thus times. Researcher divided three classes into two experimental classes and one control class. The movable book effectiveness to increasing students' curiosity was measured by questionnaire of curiosity and reinforced by observation. Questionnaires were given to two experimental classes and one control class after they finished the lesson. The experimental classes used movable book as instructional media meanwhile the control class did not use any media during learning process.

The effectiveness of the movable book was tested by applying it in learning process.Teachers performed in their classes by using movable book. The effectiveness of movablebook was measured by using curiosity questionnaire and reinforced by learning observation.Questionnaires were given to two experimental classes and one control class after finished thelesson. Observations was done by the observer during the learning process. The observer filled observation sheets that provided by researcher.The indicators of observation and questionnaire that have to be departed by observer is attached in Table 1.

Table 1. Observation indicators and questionnaires

\begin{tabular}{cl}
\hline No. & \multicolumn{1}{c}{ Curiosity indicator } \\
\hline 1 & Ask teachers and students about the material \\
\hline 2 & Enthusiastic in following learning \\
\hline 3 & Seek information from various sources \\
\hline 4 & Active and open in learning \\
\hline
\end{tabular}

Table 1 shows the indicators of observation and questionnaire which consist of fourth dimensions. Each dimensions consist of lists of enunciation which have to be filled by teacher 
and students as observer. After the data was collected, researcher put it on Microsoft Excel. The ordinal and nominal data converted to interval data using Method of Successive Interval (MSI).While the data have done converted, researcher analyzed it by using SPSS 23.

Analysis by SPSS 23 aimed to identify normality distributiontest and to examine hypothesis. The hypothesis on this research was there is influences ofstudents' curiosity by using movable book. The null hypothesis $\left(\mathrm{H}_{0}\right)$ will be accepted when the significance level is more than 0.05 . Therefore, The null hypothesis $\left(\mathrm{H}_{0}\right)$ will be rejected when the significance level is less than 0.05 .

\section{Result and Discussion}

Data obtained was qualitative data, that's why it needs to be converted into interval data. Interval data outcomes can be analyzed by using parametric statistics. Method of converting ordinal and nominal into interval data used method of successive interval (MSI) [4]. The use of interval scales for the purposes of parametric statistics is a norm to change data to have normal distribution. In order to use parametric statistical, the data must have an interval scale (and ratio) to normal distributed. If data was not normal distributed then we use nonparametric statistical [5].

Test Statistics ${ }^{a}$

\begin{tabular}{|l|r|}
\hline & \multicolumn{1}{|c|}{ value } \\
\hline Mann-Whitney U & 206.500 \\
Wilcoxon W & 1241.500 \\
Z & -3.407 \\
Asymp. Sig. (2-tailed) & .001 \\
\hline
\end{tabular}

Figure 1. Results of SPSS analysis of curiosity questionnaire

Data has been converted into interval data using MSI then data was processed by using SPSS 23 applications. The use of SPPS assisted the computation of statistics using computerized [6]. The calculation was done to decision making research hypothesis. The null hypothesis was the absence of influence of movable book to increasing the sense of the students' curiosity. The alternative hypothesis was that there is influence of applying movable book to increasing students' curiosity. The decision rule if $\mathrm{H} 0>0.05$ then $\mathrm{H} 0$ is accepted then if $\mathrm{HO}<0.05$ then $\mathrm{H} 0$ is rejected. Referring to SPSS analysis on figure 6 and figure 7, the sig level on students' curiosity observation shows 0.00 and 0.001 . The results of the analysis show $\mathrm{H} 0<0.005$ so that Ha is accepted.

The results can not be separated from outside factors of the research variables such as changes in teachers' role who proponent of movable book. Previously, teacher's role was knowledge center, but by using movable book teacher's role changed be a facilitator andstudents could learn more independently. Teacher's role exchange influenced teacher to give the students more chances to asking. Despite teacher's role exchange, students also become more enthusiastic in learning due to movable book. Regardless of outside factors, this study reflected cumulative and situational attributes, moreover the observing factors can lead increasing students' curiosity [7].

Movable book can be choosen by teachers to create effective learning. Researcher suggests to the next researcher if they want to make wonderful media, the first thing that they have to do is make a simple design. If teacher facilitate student with something new, they will 
show a great response. Student will say "wow", "cool","i like it" because they learn by using interesting media. Teacher can use variation of colors, cute animation, or variation of mechanism on movable book. Variety of aspects in movable book can lead students to understand learning by their style. One the other hand, this research just applied on narrow times and small samples. Furthermore, this research may be a reference for other researcher to develop better and useful movable book. Despite the limitations, this research requires to be follow up to find out movable book effect's with longer time and wider populations.

As efforts to building students' curiosity, teacher have to guide and facilitate students to apprehend theory so they can apply the theory in daily life. The students' perspective of knowledge based on their curiosity have to be wider, consistent, and possess the level of integration. Contrastly, a few teacher just think if teaching aims to describe and measure students' capability in learning process. Teacher does not give chance to students to comprehend the knowledge, that's why the learning process does not meaningful. In addition, teacher seems to avoid when students ask questions. Of course, that incident decrease students' curiosity. Looking for the problem, teacher have to know their role as facilitator and guide. Their job is to help students fond their own knowledge and correction wrong perpesctive on students. Opdal highlights how curiosity should be developed by the teacher, and does not ignoring students' curiosity. This research helps teachers in carrying out their duties to be a facilitator in learning to building students' curiosity.

Movable book provides transcription and pictures with catchy and good readibility. This research conducted by Lea M. McGee and Rosalind Charlesworth with "Books with movables: more than just novelties" [8]. They found that movable book can be an alternative media to be employed in learning and replace video, film, or animation. Movable book helps students to connect abstract knowledge with reality, when electronic media such as movies and videos can not be understood by them. Movable book are not just used for reading traditionally, movable book appeal knowledge with something fun and attractive. Based on psychology's side movable book motivated students to improve their concept attainment. McGee and Charlesworth inspire researcher to design movable book to counter students' curiosity.

A simple movable book can be made by the teacher even by the students with adjusting concept design. One example of simple movable book which can students create is greeting cards within simple pop up. Movable book employed as media to improving the Surabaya community's curiosity about legend in their region. That movable book was created by Azizah, Baharuddin, and Budiarjo using various mechanisms such as pop-up, flip, flap, and other movable techniques so the pupil will be motivated to reading and make it [9]. Instead the visual, animated, and existing mechanisms in line with the purpose of creating a book.

Recognising with the study, the journal written by Richar F. Abrahamson and Robert Stewart with the title "Movable Book - A New Golden Age" [10] contains movable book that were very popular in the 1980s. Movable book on that time obtained fable, mysteries, mythes, and education. The purpose of creating movable book with their diverse contents is to get readers apprehend the materials, reading with joyful, and to enhancing imagination and cognitive domains. The material which obtained in movable book in line with the purposes of making it. The advantages of movable book that can be filled with various materials inspire researcher to design a movable book which contains the potential material of the natural environment around the students in efforts to increase students' curiosity. The selection of the students' environmental science materials is appropriately assessed so the students can express their curiosity by interacting with the environment directly. 


\section{Conclusion}

Based on the research's findings, researcher concluded that movable book could be one of alternative way to solve students' low curiosity in learning process. That statement was proved by the increasing of students' curiosity after they used movable book in learning process. Although movable book was not the only one of aspects in improving students' curiosity, but it was a main factor that lead another one to increase students' curiosity.

Movable book is a main factor that distorted teacher and students' role. Movable book help students more enthusiastic in learning. Teacher also change their teaching style which ultimately help to improve students' curiosity. High curiosity can increase students' awareness of the environment and exploit the environment. The cultivation of the curiosity character of the students may initially be difficult. On the other hand, when teacher encourages students with eye contact, smile, and positive responses, it will encourage students' curiosity through questioning [7]. In other cases, embedded curiosity encourages strong therapeutic and empathic relations of patients' care in the hospital become more effective [11]. However, students' curiosity is important to develop because it is so useful in the future.

\section{References}

[1] Menteri Pendidikan Nasional Indonesia. Pembinaan Pendidikan Karakter di Sekolah Dasar. (2010)

[2] Khan, Y., "Pendidikan karakter berbasis potensi diri”, Yogyakarta: Pelangi Publishing, 2010.

[3] Anggoro S, Sopandi W, Sholehuddin M. Influence of joyful learning on elementary school students' attitudes toward science. InJournal of Physics: Conference Series 2017 Feb 1 (Vol. 812, No. 1, p. 012001). IOP Publishing.

[4] Al-Rasyid, H., "Teknik Penarikan Sampel dan Penyusunan Skala”, Pasca Sarjana UNPAD, Bandung, 1994.

[5] Walpole, R.E., "Pengantar Statistika, Edisi ke-3," Gramedia Pustaka Utama, Jakarta, 1992.

[6] Sujarweni, V.W., "SPSS untuk Penelitian," Pustaka baru press, 2014.

[7] Alexander, P.A., Pekrun, R., and Linnenbrink-Garcia, L., "Curiosity," International Handbook of Emotions in Education Routledge, 2014.

[8] McGee, L.M., and Charlesworth, R., "Books with Movables: More than Just Novelties," International Reading Sddociation 37 (9), 853-859 (1984).

[9] Azizah, F.T.N., Baharudiin, M., and Budiarjo, H., "Penciptaan Buku Pop-Up Legenda Ketintang dengan Menggunakan Teknik Movable Sebagai Upaya Konservasi Budaya Lokal Surabaya," Jurnal Desain Komunikasi Visual 5 (1), - (2016).

[10] Abrahamson, R.F., and Stewart, R., "Movable Book - A New Golden Age," Language Arts 59 (4), 342-347, (1982).

[11] Roman, B., "Curiosity: a best practice in education," Medical Education Blackwell Publishing 45, 654-656 (2011) 